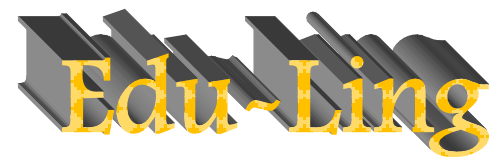

Journal of English Education and Linguistics

\title{
CHARACTER VALUES FOUND IN ENGLISH TEXTBOOKS OF SENIOR HIGH SCHOOL
}

\author{
Fetriani and Indah Hayati
}

English Study Program of UMB

E-mail: fitriwahyutama@gmail.com

Received on March, 18th, Revised on May 29th, Published on July, 30th 2019

\begin{abstract}
The objective of this research is to find out character values found in English textbook for grade ten and for grade eleven of Senior High School. The research was descriptive qualitative research which dealt with non-numerical data and focused on the character values found in English textbook of senior high school. The result of this research presented the character values found in English textbook for grade ten and for grade eleven of Senior High School. They are religiousness, honesty, tolerance, discipline, perseverance, creativity, independence, democracy, curiosity, nationalism, patriotism, appreciation, friendliness /communication, peacefulness, literacy, affection to nature, sociable, and responsible. From those 18 characters, appreciation character is the most dominant with the percentage of 12.5 $\%$. Meanwhile, tolerance, discipline, independence, democracy, and literacy characters stand in the lowest position with only $2.5 \%$.
\end{abstract}

Key Words: Character Values, English Text Book

\begin{abstract}
ABSTRAK
Tujuan dari penelitian ini adalah untuk mengetahui nilai karakter yang ditemukan di buku teks bahasa Inggris untuk kelas sepuluh dan untuk kelas sebelas SMA. Penelitian ini adalah penelitian kualitatif deskriptif yang berhubungan dengan data non-numerik dan berfokus pada nilai-nilai karakter yang ditemukan dalam buku teks bahasa Inggris sekolah menengah atas. Hasil penelitian ini menyajikan nilai karakter yang ditemukan di buku teks bahasa Inggris untuk kelas sepuluh dan untuk kelas sebelas SMA. Mereka adalah agama, kejujuran, toleransi, disiplin, ketekunan, kreativitas, kemandirian, demokrasi, rasa ingin tahu, nasionalisme, patriotisme, penghargaan, keramahan / komunikasi, kedamaian, literasi, kasih sayang terhadap alam, ramah, dan bertanggung jawab. Dari 18 karakter tersebut, apresiasi terhadap karakter adalah yang paling dominan dengan persentase 12,5\%. Sementara itu, toleransi, disiplin, kemandirian, demokrasi, dan karakter literasi berada di posisi terendah dengan hanya 2,5\%.
\end{abstract}

Kata Kunci: Nilai Karakter, Buku Teks Bahasa Inggris 


\section{INTRODUCTION}

Character is very important to be embedded in every person because by having good character, they can be good people and create a better society.If the people don't have good character, it may result to several social problems, for example; killing, raping, freesex, abortion, drug, and criminal act. As the fifthbiggest population country in the world, Indonesia needs great number ofhuman resources with good quality as the main support in nation building. The character has become urgency in creating better world.

Character can be embedded in the family, society, and school. Family, especially parents, plays an important role in educating their children about the character values. Society also is very important in the process of growth and development of a person. School is another place where a person can form his character. Educationin schools also has a big contribution in forming a person's character through the learning process and habitforming processes in students (Furkan, 2013).

As in school, curriculum is the heart ofeducation, it is better to give more attention to values education and national character in it. It is mentioned in National Education System No. 20/2003chapter 3, that the function of national education is to develop ability andbuild character in order to create an intelligible national life.The Ministry of National Education established the points of character building that must be underlined in school. They are religiousness, honesty, tolerance, discipline, perseverance, creativity, independence, democracy, curiosity, nationalism, patriotism, appreciation, friendliness or communication, peacefulness, literacy, affection to nature,sociable, and responsible (Suyadi, 2013).

According to Kemendiknas (2010) character education can be applied in avariety of elements that exist in schools, forexample in schools' curriculum and syllabus inteachers' lesson plans, materials, and media. Inthis curriculum, character building can beembodied into almost every subject. It is alsocan be embodied in lesson plan where there areindicators and measurement, the values ofcharacter building can be integrated and then it can be implemented into learning activities. Character education can also beimplemented in the learning materials so thatwhen the teacher teaches the material to thestudents, it is not only the material itself that isconveyed, but also the character educationvalues as well. 
Character ineducation should be also integrated in English. English language teaching should not just give knowledge about language, but also character input. Thus, the teachers play an important role in building the students' characters at school. They are obliged to provide good examples for the students in all aspects of knowledge taught to them.The teachers can embed character values to students in some ways. The teachers can implement the character values in teacher-students interaction or embed them by using textbook (Koesoema, 2007). It means that the material which provided in the textbook must match the character values in the curriculum.

Therefore, English textbook is materials especially designed for English learning and teaching that have been specially selected and exploited for teaching purposes. English textbook should also deals with students character explicitly and implicitly since it should not only produce high intellectual but also great character. So it is important to teachers to notice students' character by encouraging them to know and to learn more about it while learning materials. A materials implemented with character building is truly needed in this case. By using appropriate material, it is hoped the character values can be embedded well to the students.
As in government-run school English teachers uses textbook provided by government. It means the textbooks are mostly used by the teachers. The textbooks are very important since it administered to all schools in Indonesia. In curriculum 2013, Senior High Schoolstudents use textbook entitled "BahasaInggris". It is administrated by the Ministry of Education and Culture of Indonesia.These English textbooks have important role in teaching and learning process since most of Senior High Schools in Indonesia are using this textbook.

The previous research findings, studies about the character values which were to increase awareness of the change process of implementing the character education program indicated that character values is important for its success', who suggests that character values are forced to find ways to infuse the curriculum with character building. Regarding of this, PusatKurikulumdanPerbukuan(2011) mentions that National Education should lead to character building by employing character values in the lesson plan. In addition, the general objective of national education is educating Indonesian students to be religious, well-mannered, healthy, clever, creative, independent, responsible, nationalist and democratic citizens 
(Kemendikbud, 2013).

From the explanation above, character values have become important aspect in every element of education, especially at school. All school elements have responsibility in building students' characters so it is important to investigate character values in textbook. Thus the researchers proposed the research entitledCharacter Values Found in English Textbooks of Senior High School.

\section{METHODOLOGY}

\section{Design}

The research was descriptive qualitative research which dealt with nonnumerical data. Gay (1990: 189) definesdescriptive qualitative method as collecting textual data by using interpretative analysis rather than statistica lmethod. Because of that,this research dealt with analyzing English text book and interpreting the text rather than analyzing the number. Therefore, The research focused on the character values found in English textbook of senior high school.

This research employed two of English textbooks for Senior High Schoolentitled"BahasaInggris". The object of the research was the textbook for grade ten and for grade eleven of Senior High School.It is administrated by the Ministry of
Education and Culture of Indonesia.The main focuses of the research were analyzed the elements of texts and interpreted it to get the character values conveyed. There were fourteen reading texts that would be analyzed in this research. They are described below.

Table 2. Object of the Research

\begin{tabular}{cl}
\hline No & \multicolumn{1}{c}{ Title } \\
\hline $\mathbf{1}$ & Tanjung Putting National Park \\
$\mathbf{2}$ & TajMahal \\
$\mathbf{3}$ & Visiting Niagara Falls \\
$\mathbf{4}$ & Meeting My Idol \\
$\mathbf{5}$ & Heroes Day \\
$\mathbf{6}$ & B.J. Habibie \\
$\mathbf{7}$ & Cut NyakDhien \\
$\mathbf{8}$ & Issumboshi \\
\hline $\mathbf{9}$ & The Legend of MalinKundang \\
\hline $\mathbf{1 0}$ & Strong Wind \\
$\mathbf{1 1}$ & The Enchanted Fish \\
$\mathbf{1 2}$ & A Cancer That Must Be Eradicated \\
\hline $\mathbf{1 3}$ & President Sukarno of Indonesia \\
\hline $\mathbf{1 4}$ & Letter to God \\
\hline
\end{tabular}

The data were collected through the steps: 1) Read the texts several times, 2) interpreted the word conveyed by the text according to the character values analyzed, 3 ) interpreted the character value from the text according to the curriculum. 
The checklist was done to get the information from the English textbook about what character values found in English textbook of ten grade and eleven grade of Senior High School.Checklist is a list of data variable that which collected by direct contact to the object (Creswell, 2009:267).The sample of the checklist was presented below:

\begin{tabular}{|c|c|c|c|c|}
\hline \multicolumn{5}{|c|}{ TITLE: } \\
\hline \multicolumn{2}{|c|}{ Character values } & Yes & No & Indicator \\
\hline 1 & Religiousness & & & \\
\hline 2 & Honesty & & & \\
\hline 3 & Tolerance & & & \\
\hline 4 & Discipline & & & \\
\hline 5 & Perseverance & & & \\
\hline 6 & Creativity & & & \\
\hline 7 & Independence & & & \\
\hline 8 & Democracy & & & \\
\hline 9 & Curiosity & & & \\
\hline 10 & Nationalism & & & \\
\hline 11 & Patriotism & & & \\
\hline 12 & Appreciation & & & \\
\hline 13 & $\begin{array}{l}\text { Friendliness/ } \\
\text { Communication }\end{array}$ & & & \\
\hline 14 & Peacefulness & & & \\
\hline 15 & Literacy & & & \\
\hline 16 & $\begin{array}{l}\text { Affection to } \\
\text { nature }\end{array}$ & & & \\
\hline 17 & Sociable & & & \\
\hline 18 & Responsible & & & \\
\hline
\end{tabular}

The Ministry of National Education (cited in Suyadi, 2013; 8)

\section{Intra-rater Reliability}

To make valid inferences form the text, it was important that the classification procedure be reliable in the sense of being consistent. One way to measure reliability was using intra-rater reliability. It referred to the consistency of scores or answers how consistence they were for each individual from one administration of an instrument to another, and from one set of items to another. Intra-rater reliability was essentially a variation of the equivalent forms type of reliability in that the scores were produces by two raters.

The purpose ofthe intraraterwastoreviewthe wholeresearch project and to evaluate the accuracy and evaluate whether or not the findings, interpretations and conclusions were supported by the data which gavean objectiveassessmentfrom the processuntil theconclusion of the study.

\section{Data Analysis}

In this study, data analyses were conducted over the course of study. The data analyses and interpretations were based on data from the checklist. The data from the checklist were analyzed by using manual statistic. To get validity and consistency of the data, intra-rater reliability was interpreted into the percent agreement and the categories where the maximum possible total score in this rubric was above 90 (McHugh,2012). 


\section{FINDINGS AND DISCUSSION}

\section{A. The Findings of the research}

In this chapter, the researcher describes the results of the research. The data were obtained from the reading texts of English textbooks for grade $\mathrm{X}$ and grade $\mathrm{XI}$ of senior high schools regular program.

\section{Character values found in English textbook for Senior High School}

The result of this research is presented character values found in English textbook for grade ten and for grade eleven of Senior High School. They are there are 18 character values that embedded in the students as the effort to build the nation's character. They are religiousness, honesty, tolerance, discipline, perseverance, creativity, independence, democracy, curiosity, nationalism, patriotism, appreciation, friendliness or communication, peacefulness, literacy, affection to nature, sociable, and responsible. The result of this research can be seen in the following table:

Table 5. Types of Character Values Found in English Textbook for Senior High School

\begin{tabular}{clcc}
\hline No & $\begin{array}{c}\text { Character } \\
\text { Value }\end{array}$ & $\begin{array}{c}\text { Frequency } \\
\text { (f) }\end{array}$ & $\begin{array}{c}\text { Percen- } \\
\text { tage } \\
(\boldsymbol{\%})\end{array}$ \\
\hline $\mathbf{1}$ & Religiousness & 2 & $5 \%$ \\
$\mathbf{2}$ & Honesty & 2 & $5 \%$ \\
$\mathbf{3}$ & Tolerance & 1 & $3 \%$ \\
\hline $\mathbf{4}$ & Discipline & 1 & $2.5 \%$ \\
\hline
\end{tabular}

\begin{tabular}{|rlcc|}
\hline $\mathbf{5}$ & Perseverance & 3 & $7.5 \%$ \\
\hline $\mathbf{6}$ & Creativity & 2 & $5 \%$ \\
$\mathbf{7}$ & Independence & 1 & $2.5 \%$ \\
$\mathbf{8}$ & Democracy & 1 & $2.5 \%$ \\
$\mathbf{9}$ & Curiosity & 2 & $5 \%$ \\
$\mathbf{1 0}$ & Nationalism & 2 & $5 \%$ \\
$\mathbf{1 1}$ & Patriotism & 2 & $5 \%$ \\
\hline $\mathbf{1 2}$ & Appreciation & 5 & $12.5 \%$ \\
\hline $\mathbf{1 3}$ & Friendliness/com. & 4 & $10 \%$ \\
\hline $\mathbf{1 4}$ & Peacefulness & 2 & $5 \%$ \\
\hline $\mathbf{1 5}$ & Literacy & 1 & $2.5 \%$ \\
\hline $\mathbf{1 6}$ & Affection to & 2 & $5 \%$ \\
& nature & & \\
$\mathbf{1 7}$ & Sociable & 4 & $10 \%$ \\
\hline $\mathbf{1 8}$ & Responsible & 3 & $7.5 \%$ \\
& TOTAL & 40 & $100.0 \%$ \\
\hline
\end{tabular}

From the table above, it is shown that appreciation appears more frequent which is five $(12.5 \%)$, and followed by sociable and friendliness which appears four (10\%). Perseverance and responsible appears three times $(7.5 \%)$ of each them. Religiousness, honesty, creativity, curiosity, nationalism, patriotism, peacefulness, and affection to nature appears two times $(5 \%)$ of each them. Finally, tolerance, discipline, independence, democracy, and literacy are the less frequent which are one $(2.5 \%)$.

\section{B. Discussion}

Based on previous explanation, the result of research revealed the finding posted in the research question. It showed that English textbook for senior high school. The finding shows that there are eighteen 
character values appear in the textbook. The 2013 curriculum and the objective displayed the book were used in this study can be seen based the findings. Mulyasa (2013) stated that character in education and science education are mutually relevant, both developing virtues and propositional knowledge as moral decision making is developed with science without indoctrination.

The findings of this result reveals that it is shown that appreciation appears more frequent which is five $(12.5 \%)$, and followed by sociable and friendliness which appears four $(10 \%)$. Perseverance and responsible appears three times $(7.5 \%)$ of each them. Religiousness, honesty, creativity, curiosity, nationalism, patriotism, peacefulness, and affection to nature appears two times (5\%) of each them. Finally, tolerance, discipline, independence, democracy, and literacy are the less frequent which are one $(2.5 \%)$.

Based on the result above, the textbooks cover all the 18 values which promoted by national education which are religiousness, honesty, tolerance, discipline, perseverance, creativity, independence, democracy, curiosity, nationalism, patriotism, appreciation, friendliness communication, peacefulness, literacy, affection to nature, sociable, and responsible. All the values are important to help students to make their better personality. Therefore, all the values are provided in the textbooks. As Suyadi (2013) stated that character values are purposed to build the students' ethical. By using character values in education, the student are hoped to have responsible, decrease to immoral actions.

In concept of integrated curriculum, character value that is integrated to the science should be relevant. Moral education as in character building should be integrated to the English Material. In this case, the selected textbook is book which is developed by using 2013 curriculum, integrates moral education in the material. Character development has long been one of the goals of national education. One of the national education goals is to develop the learner's potential, intelligence, personality, and noble character. In this case, education is intended not only to establish intelligence, but also to develop personality or character (Hapsari, 2013:2).

Furthermore, the character values not only can be embedded in in reading section of textbooks, but also in varies ways in schools, for instance in schools' curriculum and syllabus in teachers' lesson plans, materials, and media. In this curriculum, character values can be embedded into almost every subject. It is also can be embodied in lesson plan where there are 
indicators and measurement, the values of character building can be integrated and then it can be implemented into learning activities (Kemendiknas, 2010).

The result of this research is similar with Hapsari (2013:5) which stated that textbook holds important role because the textbook is one of the sources of information and an effective tool to increase their experiences. In addition, the material presented in textbooks may be used as consideration in teaching. textbooks. Reading is always a part of a textbook. More than a half of materials in textbooks usually even come from this reading part. In reading section of a textbook, students can find so much information. This condition makes reading an effective medium to embedded character values into. Students will not only get information for their studies, but they can also learn good character values to help stirring them to the right path through their adolescence.

In sum, English textbook is especially designed for English learning and teaching that have been specially selected and exploited for teaching which not only to transfer knowledge, but also to embed character values. English textbook should also deals with students character since it will produce both high intellectual and great character. So, it is important to teachers to embed students' character by encouraging them to know and to learn more about it while learning materials.

\section{CONCLUSION AND SUGGESTION}

\section{Conclusion}

The result of present study shows that characters that are found in the texts of English textbook entitled Bahasa Inggris for Grade X and for Grade XI of Senior High Schools cover 18 characters described by Kemendikbud. Those characters cover all the 18 values which promoted by national education which are religiousness, honesty, tolerance, discipline, perseverance, creativity, independence, democracy, curiosity, nationalism, patriotism, appreciation, friendliness /communication, peacefulness, literacy, affection to nature, sociable, and responsible. From those 18 characters, appreciation character is the most dominant with the percentage of $12.5 \%$. Meanwhile, tolerance, discipline, independence, democracy, and literacy characters stand in the lowest position with only $2.5 \%$.

\section{Suggestion}

Based on the conclusion above, there are some suggestions provided in his research. For principals, supervisors, and head of education. It is suggested to pay more attention to the circulation of textbooks used in schools. It is intended to support the 
integrated character education development in all subjects, especially English. In addition, all element should pay attention to the condition of all educational components to support the implementation of character education.

For teachers. It is suggested to be more selective in choosing books or instructional materials and activities that already exist in the textbook for the application in the classroom. Teachers should be able to raise or deliver characters of character education in the material or activity explicitly. Teachers should integrate these characters optimally.

For next researcher. It is suggested to conduct relevant research about character values in larger scope. In addition, it is also important to conduct research related to strategies in implementing character values.

\section{REFERENCES}

Furkan, N. 2013. Pendidikan Karakter melalui Budaya Sekolah. Yogyakarta: Magnum Pustaka Utama.

Gay, L.R and P. Airisian. 2000. Educational Research: Competencies for Analysis and Application ( $\left.6^{\text {th }} e d\right)$. New Jersey: Prentice Hall.

Hapsari, PratamaLysa. (2013). Character Education Values in Reading Section of E-English Textbook for Senior High
School Students Grade XI.English Language Teaching Forum.Retrieved on $12^{\text {th }}$ August 2017 from http://journal.unnes.ac.id/sju/index.ph p/elt.

Kemendiknas. 2010. Desain Induk Pendidikan Karakter. Jakarta: Kemendiknas.

Koesoema A. D. 2007. Pendidikan Karakter: Strategi Mendidik Anak di Zaman Global. Jakarta: Grasindo.

McHugh,M. 2012. Interrater Reliability: the Kappa Statistic. Biochemia Medica 2012;22(3):276-82. Retrieved on May $5^{\text {th }} \quad 2017 \quad$ from http://dx.doi.org/10.11613/BM.2012.0 31.

Mulyasa, H.E. 2013. Pengembangan dan Implementasi Kurikulum 2013. Bandung: PT Remaja Rosdakarya.

Pusat Kurikulum dan Perbukuan. 2011. Pedoman Pelaksanaan Pendidikan Karakter. Jakarta: Pusat Kurikulum dan Perbukuan, Badan Penelitian dan Pengembangan Kementerian Pendidikan Nasional.

Suyadi. 2013. Strategi Pembelajaran Pendidikan Karakter. Bandung: Remaja Rosdakarya. 